Boise State University

ScholarWorks

Political Science Faculty Publications and

Presentations

Department of Political Science

9-1-2011

\title{
Political Polarization as a Constraint on Corruption: A Cross-National Comparison
}

David S. Brown

University of Colorado

Michael Touchton

Boise State University

Andrew Whitford

University of Georgia

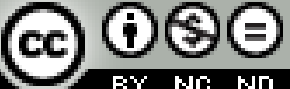

This is an author-produced, peer-reviewed version of this article. (C) 2009, Elsevier. Licensed under the Creative Commons AttributionNonCommercial-NoDerivatives 4.0 International License (https://creativecommons.org/licenses/by-nc-nd/4.0/). The final, definitive version of this document can be found online at World Development, doi: 10.1016/j.worlddev.2011.02.006 


\title{
Political Polarization as a Constraint on Government: Evidence from Corruption
}

\author{
David S. Brown \\ University of Colorado \\ Michael Touchton \\ Boise State University \\ Andrew Whitford \\ University of Georgia
}

\begin{abstract}
Efforts to explain corruption have increased dramatically in recent years. The interest stems from the increasing weight economists assign to corruption when explaining economic growth. Much research focuses on how political institutions influence perceptions of corruption. We move this debate in a new direction by addressing a previously ignored dimension: ideological polarization. We contend perceptions of corruption are determined not only by specific institutional features of the political system - such as elements of voting systems, ballot structures, or separation of powers - but by who sits at the controls. We employ panel data from a broad variety of countries to test our theoretical argument. Contrary to recent findings by both economists and political scientists, we show that ideological polarization predicts perceptions of corruption.
\end{abstract}

\section{Introduction}

Understanding the causes of corruption occupies the full attention of scholars interested in economic growth and democracy. Economists now believe corruption severely constrains economic growth (Mauro, 1995, Ehrlich and Lui, 1999, Kaufman and Wie, 1999, Kaufman, et. Al. 2003) Contracts and licenses based on bribery decrease the incentives to invest by reducing the difference between productive and non-productive investment (Mauro, 1995, Murphy, et al. 1993). Funds for public infrastructure projects diverted to politicians' personal bank accounts reduce economic growth (Bardhan, 1997). Of course, corruption influences politics as well: by short-circuiting the connection between the electorate and its representatives, corruption can cause civil unrest (e.g., China, the Ukraine, Kyrgyzstan) and is associated with poor government performance (Bardhan, 1997). Coupled with the advent of new ways to measure it, corruption's newfound importance has generated an extensive literature in the last few years. ${ }^{1}$ Corruption is not merely an academic concern. Multilateral lending agencies and international aid organizations now consider corruption to be one of the biggest obstacles to economic development. Past World Bank President James Wolfensohn put the case firmly: "let's not mince words", he declared at the World Bank's annual meeting in 1996, "we need to deal with the causes of corruption" (The Economist, June $4^{\text {th }}, 2005: 66$ ).

Recent research emphasizes political institutions (Myerson, 1991, Carey and Shugart, 1995, Panizza, 2001, Montinola and Jackman, 2002, Person and Tabellini, 2003, Seddon, et al. 2003). For example, Persson and Tabellini (2003) emphasize electoral rules and the form of government (presidentialism versus parliamentarism). Kunicová and Rose-Ackerman (2005) focus as well on basic institutional choices made in constitutional design, arguing that very specific electoral rules can have a considerable impact on corruption. Montinola and Jackman (2002) find a nonlinear relationship between democracy and corruption, arguing that institutionally-defined constraints can challenge corrupt practices. Persson and Tabellini (2003) argue small electoral districts encourage corruption by limiting political competition. In small districts, large national parties can dominate, raising the barriers to entry for likely challengers. Electoral rules also matter: selecting politicians through party lists, it is argued, obscures the direct link between voters and politicians, degrading the ability of voters to hold politicians accountable (Persson and Tabellin, 2003, Kunicova and Rose-Ackerman, 2005). 
NOTICE: This is the author's version of a work accepted for publication by Elsevier. Changes resulting from the publishing process, including peer review, editing, corrections, structural formatting and other quality control mechanisms, may not be reflected in this document. Changes may have been made to this work since it was submitted for publication. The definitive version has been published in World Development, Volume 39, Issue 9, 2011. DOI: 10.1016/j.worlddev.2011.02.006

Whether emphasizing executive-legislative relations, the electoral system, or democracy itself, scholars generally ignore who is engaged in political struggle. ${ }^{1}$ This is surprising given that political struggles between politicians of similar ideological orientations are likely to produce very different outcomes when compared to those produced by politicians with diverse interests and ideologies. The lack of interest is curious since ideological differences are an important component of the veto player argument to which most of the work in this literature refers. Tsebelis (1995) argues that the coherence of each group (party cohesion) and their congruence (ideological difference among different parties) is of equal importance to the number of veto players when explaining policy stability. Previous empirical work also cautions against ignoring polarization. For example, Keefer and Stasavage (2003) show that inflation expectations are not only influenced by the checks and balances associated with the policy process but also by the ideological polarization that characterizes the legislature. Because previous research on corruption focuses so closely on institutional determinants without considering congruence or coherence, emphasis on institutional structures as the predominant cause of corruption may be misplaced. In the case of corruption, ideological polarization may increase incentives for politicians to expose corrupt practices by the opposition.

Accordingly, we account for a defining characteristic of legislative politics: polarization, measured as the ideological distance between institutional actors. We provide evidence for this position by estimating the correlation between ideological polarization and cross-national assessments of corruption. Parameter estimates of polarization are substantively important and statistically significant. We then unpack the polarization variable and find that the relationship between polarization and corruption is non-linear: movements from the lowest values of polarization to values around the mean have little impact on perceptions of corruption; moving further up the polarization scale dramatically increases the perception that corruption is being controlled. The estimates imply that governments faced with an opposition positioned in the middle of the political spectrum are no less likely to engage in malfeasance whereas governments faced with an opposition at the ideological extreme have no such opportunity.

Consequently, our estimates have even broader implications for party systems, electoral laws, and executivelegislative relations. The relative importance of polarization not only stands up to other institutional variables, our estimates of polarization are informed by a model that accounts for unit effects and additional controls. In particular, the effect of polarization on perceptions of corruption is as strong as the effect of electoral rules on corruption, a key finding reported in previous work (Persson and Tabellini, 2003, Kunicova and Rose-Ackerman, 2005). These results hold important implications for both scholars and practitioners interested in promoting honest and accountable government: institutions do not perform uniformly across time and space. The efficacy of institutionalized constraints, the results suggest, depends on who is being constrained and who is doing the constraining.

Our paper proceeds as follows. The first section summarizes the literature on corruption and the rationale for examining ideological polarization in conjunction with institutional rules. The second section describes the difficulty with previous analyses, while the third describes the variables and methodology we employ. Finally, we describe our results, discuss the implications of our findings, and identify a direction for future analysis of institutions and corruption.

\section{Theory}

Most theory focuses on formal rules and their impact on the credibility of political commitments. Specifically, scholars emphasize the institutional mechanisms that constrain political actors to explain corruption. Institutional structures prominently featured in the literature are electoral rules, rules that govern the interaction between the executive and legislature, the number of checks within the policymaking process (veto players), democratization, and federalism (Lijphart, 1999, Persson and Tabellini, 2003, Kunicova and Rose-Ackerman, 2005).

We argue that the focus on institutional rules neglects the interests that inhabit these institutions. Proponents of single-member plurality systems argue, for example, that one elected official for each district provides a direct mechanism through which voters can hold politicians accountable. Who occupies the legislature is irrelevant; the degree to which interests differ in a legislative body is inconsequential. Fans of presidential regimes make a similar argument: elected directly by the entire population, presidents are highly scrutinized, making it more difficult for the chief executive to engage in corrupt practices. Opponents of presidentialism argue from a contrasting vantage point:

\footnotetext{
${ }^{1}$ The exception here is Alt and Lassen (2004) who take the impact of divided government on corruption into account in the context of the American States.
} 
NOTICE: This is the author's version of a work accepted for publication by Elsevier. Changes resulting from the publishing process, including peer review, editing, corrections, structural formatting and other quality control mechanisms, may not be reflected in this document. Changes may have been made to this work since it was submitted for publication. The definitive version has been published in World Development, Volume 39, Issue 9, 2011. DOI: 10.1016/j.worlddev.2011.02.006

independent, unconstrained executives have more opportunities to engage in suspect political behaviour, including corruption. ${ }^{2}$ In both cases, the political orientation of the chief executive in relation to the legislative body is unimportant. Finally, others emphasize the number of veto players. As the number increases, the difficulty associated with engaging in corruption increases. With more checks in place, corruption is relatively more constrained. In this case, we know the numbers, but we do not know whether they represent ideologically opposed positions on the political spectrum. Below we present the various formal mechanisms and their theoretical connection to rent extraction.

\section{Political Polarization}

We start our discussion with what is missing from consideration in the theoretical literature: the degree to which political actors represent distinct political viewpoints or ideologies. The variance in political behaviour among actors that inhabit political institutions is absent from consideration. Empirically, our conception of behavioural variation is captured best by ideological polarization. We argue that institutional variations only capture half of the core dynamic of political systems. The actions of political actors in a political system also drive perceptions of how political systems operate.

We test whether politicians are more likely to behave as agents of the public good when confronted with an opposition that is unlikely to collude. While Persson, et al. explore this relationship in the context of the separation of powers, we take it a step further: we expect polarization will influence collusion between politicians even in the absence of institutional checks and balances (Persson et. al., 1996). For example, opposition politicians may have a strong incentive to ignore corrupt practices by the government if the probability of future coalition building is high; oppositions representing more ideologically distinct platforms will be less likely to enter into coalitions, removing any hesitation to bring the government down. In other words, increased polarization increases conflict between incumbent and opposition parties. Under these conditions, polarized politicians behave much like the politicians in Persson, Roland, and Tabellini's extensive form game involving separate branches of government (1996). This does not only reflect the impact of divided government as discussed in Alt and Lassen (2005). Instead, the measure addresses the ideological distance between parties. The logic of capturing this element of politics is best illustrated with the following simple example. In the United States, it may be relatively easy for a Republican administration to recruit defectors from the Democratic Party to support any given 'Republican' issue. Given the greater ideological distance, recruiting potential defectors from the Green Party, however, is a more difficult proposition. Since it is unlikely the Green party will ever rely on a coalition with the Republican Party, there is less hesitation among its leadership and members to expose malfeasance by the Republicans.

We recognize that an alternative effect of polarization on corruption is possible. In contrast to the previous example, there are theoretical reasons to believe low levels of polarization may increase corruption: ideologically similar parties may face powerful incentives to report one another's corruption precisely because there is no other way to distinguish themselves from each other. Like-minded parties often form coalitions with one another, but lack issues by which to distinguish themselves. Ideologically similar parties would therefore lodge charges of corruption against one another in order to gain ground at the expense of their ideological neighbour. If this alternative effect is present, we should observe a correlation between lower levels of polarization and increased corruption. While our central claim is that polarization decreases corruption, our approach is designed to determine which claim receives the most empirical support.

We claim ideologically opposed groups have greater incentives to reveal malfeasance than ideologically similar parties. Forced to deal with an ideologically similar political party, both the incentive and opportunity exists to distribute rents to buy support. Put simply, an opposition located relatively close to the government's position on the ideological spectrum will not serve as a strong check against corruption. As the distance between the executive's party and its competition grows, the incentive to distribute rents to its competition remains, but the size of rents required to placate other parties makes purchasing their support more expensive. Our claim is simple: as the price for collusion increases, the probability that opposition parties will expose corrupt members of the government increases as well.

Of course, rational observers may expect political actors to make allegations of corruption whether the corruption is real or imagined in order to undermine support for incumbent parties. Whether real or imagined, charges of corruption can affect perceptions. We expect perceptions of a political system's corruption to increase along with the 
NOTICE: This is the author's version of a work accepted for publication by Elsevier. Changes resulting from the publishing process, including peer review, editing, corrections, structural formatting and other quality control mechanisms, may not be reflected in this document. Changes may have been made to this work since it was submitted for publication. The definitive version has been published in World Development, Volume 39, Issue 9, 2011. DOI: 10.1016/j.worlddev.2011.02.006

frequency of either true or false reports of corrupt practices. However, we do not anticipate a problem with false reports as we argue executive parties will refrain from corrupt behaviour as they recognize the opposition's incentives to report malfeasance accurately. The opposition, in turn, would eventually lose credibility and political advantage were they to falsely accuse incumbents of corruption with any frequency. We therefore expect parties to refrain from such charges in the aggregate. Still, we acknowledge the possibility of an incentive structure favouring reckless accusations of corruption from opposition groups and examine the assertion against available data. Determining whether or not opposition groups are given incentives to "cry wolf" provides further impetus to explore the relationship between polarization and corruption.

The logic we have presented here is connected to other literatures emphasizing polarization's importance. As an example, Tsebelis (2002) argues an additional rationale for investigating polarization's impact on politics, arguing that three important considerations determine the importance of veto players: the number of veto players, the coherence of opposition groups, and their ideological distance from those in power (congruence). In practice, both the ideological composition of the legislature and its ideological distance from the executive influence institutional constraints. According to this logic, more ideologically polarized systems provide the level of constraints necessary to produce credible political commitments. In this way, ideologically distant actors serve as greater checks on the behaviour of their opposite number than do ideologically similar actors. We use a similar logic to generate hypotheses on the constraints politicians place on each other regarding corruption: with polarization, corruption becomes more difficult.

Although no previous empirical work addresses the relationship between political polarization and rent extraction in a cross-national context, a number of empirical studies both directly and indirectly support our logic. In their study of central bank independence, Keefer and Stasavage (2003) find that strong differences between the preferences of veto-players in the government supplement the institutions underpinning checks and balances: the greater the ideological distance between members of government, the greater the impact checks and balances have on policy outcomes. Their empirical results inform our argument that the policy positions of veto players are an important dimension supporting institutional checks and constraints. Additional empirical work on economic performance in Russia and the former Soviet Republics illustrates the importance of ideological polarization. Frye (2002) argues that polarized legislatures in Russia and the former Soviet Republics reduce the ability for politicians to credibly commit to sound economic policies. ${ }^{3}$ The strength of the communist party in the legislature causes private actors to question whether neo-liberal economic policies will be sustained. Frye shows that in Bulgaria and the Ukraine (countries characterized by a strong communist opposition) economic growth has been slow. In Estonia and Uzbekistan (with a relatively small communist presence in the legislature) economic growth has been relatively strong. Note that in Frye's work, polarization decreases the credibility that private actors assign to economic reform. In the case of corruption, the same legislative intransigence that reduces the ability to credibly commit to enacting economic reform may increase the credibility private actors assign to important oversight functions associated with corruption. The same legislative intransigence that stifles economic reform may also serve to strengthen those institutions that constrain corruption. Similarly, Kunicova and Rose-Ackerman (2005) point out the ways in which systems favouring pork-barrel politics might reduce corruption and vice-versa. Theoretically, these studies point to an interesting paradox that has so far escaped scholars: some political phenomena - in our case, polarization - may actually provide credibility in some issue arenas but not in others. Institutions that bolster the ability of politicians to make credible commitments in some issue areas may not always hold beneficial consequences in others. This possibility opens up a number of important directions for further research, both empirically and theoretically. We limit our expectations here to the case of corruption, and offer the hypothesis that corruption will be lower when polarization is higher.

Finally, recent work by Alt and Lassen (2003) suggests that who controls the levers of government matters. In addition to finding important institutional effects on corruption in the 50 United States, Alt and Lassen report divided government (opposing parties occupy the legislature and the governorship) has a negative but not statistically significant correlation with corruption. Also, the authors argue that additional institutions may complement the impact of divided government (in our case, polarization) (Alt and Lassen, 2005). The empirical findings Alt and Lassen cull from the American state governments indicates that corruption diminishes if an opposition challenges incumbent politicians (through divided government or an elected, independent judiciary). 
NOTICE: This is the author's version of a work accepted for publication by Elsevier. Changes resulting from the publishing process, including peer review, editing, corrections, structural formatting and other quality control mechanisms, may not be reflected in this document. Changes may have been made to this work since it was submitted for publication. The definitive version has been published in World Development, Volume 39, Issue 9, 2011. DOI: 10.1016/j.worlddev.2011.02.006

\section{Electoral Rules}

Recent studies focus on the roles of proportional representation (PR) and single-member plurality (SMP) systems generally, and various forms of PR systems specifically. Persson and Tabellini (2003) theorize why the distinction between PR and SMP systems influences corruption. Individual ballots under majoritarian systems, the argument goes, provide direct accountability for politicians, reducing opportunities for corruption. Yet at the same time, Persson and Tabellini note that the higher barriers to entry normally associated with smaller districts (a characteristic of plurality systems) give politicians more room to manoeuvre. When political competition is relegated to a relatively few number of candidates in each district, political outsiders will have relatively fewer opportunities to challenge corrupt incumbents. Finally, Kunicova and Rose-Ackerman (2005) contend revelation of incumbent corruption is a public good aiding all opposition parties. Parties are therefore more inclined to reveal incumbent malfeasance when they have the most to gain- most likely when they are the only major opposition party. A two party, SMP system would generate such opportunities more frequently than a PR system. The theoretical expectation, therefore, is ambiguous: whether SMP or PR produces more rent-seeking behaviour depends on the relative importance of each contradictory institutional mechanism (size of district vs. district magnitude).

Kunicová and Rose-Ackerman (2005) contend proportional representation systems offer additional opportunities for rent extraction because they concentrate political rents at leadership positions in safe districts. This is particularly so in closed-list systems where party elites determine candidate positions on the ballot list and can allocate the gains from corruption to faithful MPs. ${ }^{4}$ It is more difficult for either voters or opposition parties to monitor political behaviour in PR systems, in part because of the large districts common to PR systems, but also because of the incentive structure. In PR systems, possible future coalition building may prevent opposition parties from exposing a corrupt incumbent. Furthermore, Kunicová and Rose-Ackerman argue large districts - common to PR systems also provide a more difficult environment for voters to solve the collective action problems associated with monitoring corrupt officials. In smaller districts, small groups of voters more easily organize to throw the rascals out.

Theoretical reasons exist to expect the opposite of Kunicová and Rose-Ackerman's theoretical and empirical results. Bingham-Powell (2000) argues that proportional representation systems generally outperform plurality systems when translating votes into either majority governments or coalitions close to the median voter. Plurality winners do not often hold views close to those of the median voter, yet are afforded a legislative majority. Consequently, plurality winners avoid negotiating with smaller parties across the ideological spectrum. As a result, lower public accountability is evident in SMP systems since voters' preferences may not be translated into acceptable policies. Contrary to the findings of Kunicová and Rose-Ackerman, Bingham-Powell's research implies less accountability in plurality systems, suggesting higher levels of corruption. In a more direct vein, Myerson (1993) argues for the utility of PR. Using a game theoretic analysis of voting rules, Myerson finds that PR serves as an effective deterrent to corruption. For Myerson, PR is associated with larger district magnitude, increasing the probability that voters will find candidates that both represent their interests and do so without resorting to corruption.

To summarize, although there are contrasting theoretical expectations, recent empirical work on corruption finds PR systems are associated with higher levels of corruption than their majoritarian counterparts. Kunicová and RoseAckerman along with Persson and Tabellini also find that very specific rules governing elections are more important than the crude distinction between plurality and majoritarian systems. Kunicová and Rose-Ackerman (2005) find important distinctions between open-list PR (OLPR) and closed-list (CLPR) whereas Persson and Tabellini (2003) identify district size as an important characteristic (smaller districts are associated with more corruption). Myerson (1991) argues for the utility of open-list PR systems in constraining corruption.

\section{Presidentialism vs. Parliamentarism}

The broad institutional distinction between presidential and parliamentary regimes represents another main current in the literature. ${ }^{5}$ Some scholars argue, for instance, that the centralization of power under presidential arrangements offers executives greater opportunities for rent-seeking behaviour than does the legislative authority wielded by the leadership in parliamentary systems(Mainwaring, 1995, Shugart, 1999, Kunicova and Rose-Ackerman, 2005). While in presidential systems both the party leadership and the chief executive must approve legislation, the president controls certain rents independent of a legislative check, and may even create new rents via executive orders. With 
NOTICE: This is the author's version of a work accepted for publication by Elsevier. Changes resulting from the publishing process, including peer review, editing, corrections, structural formatting and other quality control mechanisms, may not be reflected in this document. Changes may have been made to this work since it was submitted for publication. The definitive version has been published in World Development, Volume 39, Issue 9, 2011. DOI: 10.1016/j.worlddev.2011.02.006

this unconstrained authority over the creation and distribution of rents, presidents are more likely to engage in inappropriate political behaviour than are prime ministers (Baldez and Carey, 1999). Parties are stronger in parliamentary systems, and checks are weaker because parties in presidential systems are not required to organize to form governments. Additionally, the uncertain timing of elections may act to constrain parliamentary leadership due to the constant threat of no-confidence votes and subsequent dissolution. Despite empirical evidence for the viewpoint above, some argue presidential systems are better at fighting corruption. The argument is a familiar one: presidents are elected from a national constituency, providing a direct line of accountability between principal and agent (Lijphart, 1984, Mainwaring, 1995, Shugart, 1999, Cox and Morganstern, 2001, Persson and Tabellini, 2003).

\section{Veto Players, Democratization, and Federalism}

As noted above, recent contributions emphasize veto players (Tsebelis, 1995, Keefer and Stasavage, 2003). The veto player framework subsumes many institutional arguments by identifying a key dimension among all of them: the number of decision points that define the legislative process. In many respects, the theoretical discussion about political institutions falls along this line of argumentation. The ability of institutions to impact policy largely depends on how many veto players participate in the legislative process. Veto player arguments generate two conflicting sets of expectations. For some, greater checks (more veto players) increase the number of individuals who can alter or stop proposals as they wind their way through the legislative process. Consequently, a wider range of interests can influence policy by requiring larger, more widespread support to push through legislation. Beholden to more encompassing interests, the ability for politicians to generate rents through illegal activity diminishes. In direct contrast to this view some argue that a complicated and circuitous legislative process can also make it difficult for citizens to hold politicians accountable, ultimately increasing corruption. Since there is theoretical justification for either a positive or negative relationship between the number of veto players and rent extraction, we have no firm expectation regarding the empirical relationship.

The remaining institutions we analyze are directly or indirectly associated with the concept of veto players. Democratization, for example, is a process that increases the number of veto players through political competition, constraints on the chief executive, and participation by an electorate. According to Kunicová and Rose-Ackerman (2005), participation, political competition, and constraints on the chief executive all increase the ability of the population to monitor and legally constrain politicians from engaging in corrupt behavior. Montinola and Jackman (2002) find a strong nonlinear relationship between democratization and corruption. In the early stage of democratization, rent-seeking behaviour actually increases. Only after a certain level of democratization is reached will corrupt politicians face sufficient pressure.

Finally, federal systems may increase representation (reducing corruption), but may also reduce accountability (increasing corruption). Local elections may provide voice to ignored populations, but monopolization of power at the local level may also decrease the degree of accountability. There is empirical evidence, however, that federal systems are generally more corrupt than unitary systems. ${ }^{6}$ As the political pie is divided among more geographic entities, opportunities to generate political rents increase.

\section{Model Specification and Estimation}

Our variable of interest is polarization, which describes the concentration of political authority and competition between the executive and legislative branches. Although polarization can be measured in a number of different ways, we chose a measure that has been used in previous work (Keefer and Stasavage, 2003). The measure we use was constructed by Beck, et al. (2001) as follows. The largest four parties and the executive party are situated on a left-right spectrum based on economic attitudes. Pair-wise comparisons are made among those parties. The greatest ideological distance that exists between parties in pair-wise comparisons is used to indicate the degree of polarization. The largest difference between parties can occur within the governing coalition or between the government and opposition. Rather than recording the ideological distance among all parties in the system, the measure registers what we think is a more meaningful measure: the ideological distance among the four most powerful parties holding seats regardless of coalition membership. ${ }^{7}$ Simply put, the measure identifies the level of ideological pluralism among nationally-elected officials. Polarization is coded zero if the executive's party controls an absolute majority in the legislature or if elections are deemed "uncompetitive". ${ }^{8}$ Polarization is coded one if elected bodies only feature centre-left or centre-right representation among the largest parties. Polarization is coded two in states featuring a large left and right-wing presence among elected officials. It is important to note that the 
NOTICE: This is the author's version of a work accepted for publication by Elsevier. Changes resulting from the publishing process, including peer review, editing, corrections, structural formatting and other quality control mechanisms, may not be reflected in this document. Changes may have been made to this work since it was submitted for publication. The definitive version has been published in World Development, Volume 39, Issue 9, 2011. DOI: 10.1016/j.worlddev.2011.02.006

measure is different from simple measures of divided government: our polarization measure does not identify divided government. The measure's added value lies in recording the presence of ideological opposition or alliance within nationally- elected bodies.

Polarization scores for Argentina demonstrate the logic of the measure. Argentina scores a one in 2002, indicating minor economic policy differences between President Fernando de la Rua's UCR-Fre-Pa-So alliance and the Justicialist Party in control of the Chamber of Deputies. In this case, none of the four largest parties in the Chamber deviated from the executive's economic policy platform by more than one unit on the Left-Centre-Right continuum. Following the 2003 election, however, Argentina scores a zero reflecting Nestor Kirchner and his Front for Victory's ascension to the presidency. There were negligible economic policy differences between Kirchner's ensemble party and the allied Justicialists, the party with an absolute majority in the Chamber of Deputies.

This coding system allows us to test whether partisan strength influences perceptions of corruption. A positive correlation between polarization and the perceived control of corruption supports the argument that greater polarization mitigates corruption. A negative correlation signifies the need for similar parties to differentiate themselves by exposing each other's corruption. An alternative explanation for any negative association between polarization and control of corruption would be that greater polarization actually encourages illegal behaviour: opposition groups could levy false accusations of corruption against incumbents with such frequency that the public no longer finds the charges credible. In this case, incumbent parties would be free to engage in all manner of corruption as monitoring by opposition groups would not be credible. We employ information about polarization in two ways. First, we conceive of a linear relationship between polarization and perceptions of corruption, with countries scoring 0,1 , or 2 on our polarization scale. We also entertain the theoretical possibility that the relationship between polarization and perceptions of corruption is non-linear: moving from 0 to 1 on the polarization scale may not produce the same amount of change as moving from 1 to 2 . To avoid imposing linearity on the data, we specify a model that allows for very different reactions to no polarization (0), minimal polarization (1) and high degrees of polarization (2). Toward that end, polarization is specified as a series of categorical variables in order to remove restrictions associated with linearity.

Our dependent variable is the aggregated response to a number of questions regarding individuals' experience with the exercise of public power for private gain, the effects of corruption on the business environment, experience regarding state capture, etc. It is compiled by the World Bank through the solicitation of survey responses from elite actors within a given state regarding the frequency of extra payments to "get things done" and responses to other broad questions regarding the predatory nature of the state. This measure contains data compiled by the World Bank's Governance Matters V project and covers an average of 213 countries between 1996 and 2005. ${ }^{9}$ Project researchers produce a lower dimensional representation of the sources for each country as their best estimate of that state's governance with the weights being proportional to the reliability of each source. The resulting aggregate governance indicators have an expected value (across countries) of zero, and a standard deviation of one. Almost every score lies between -2.5 and 2.5, with higher scores corresponding to better governance (lower corruption). The original data were gathered from up to fifteen different sources (including the Afrobarometer, Freedom House, Gallup International, Political Risk Services, U.S. Department of State, and World Bank) for a given year. We want to be clear that we believe each new strobe in the time series provides new information about perceived corruption. Specifically, in the data we employ in this paper, the mean strobe-over-strobe change in the corruption index level is roughly zero but its standard deviation is 0.29 .

We constructed a panel dataset for the years 1996, 1998, 2000, 2002, 2003, and 2004 from a variety of databases on corruption and other aspects of the included countries to test our hypotheses (starting in 2003 the World Bank now collects these data on an annual rather than biennial basis). We believe that each measurement provides new information about how our included variables are changing the public perceptions of corruption in each country. To hedge our bets, we performed the analysis using the same model but with averaged data, estimating a purely crosssectional model. We found that the panel structure we use in our estimations is not driving our results. The estimates and the conclusions we draw from them were replicated in the cross-sectional model (see Table A3). ${ }^{10}$

We estimate a series of statistical models to assess the basis for perceptions of corruption. We begin by estimating our baseline model on 100 countries measured in 1996, 95 countries in 1998, 99 countries in 2000, 102 in 2002, 95 in 2003, and 50 in 2004. (The full list of countries is provided in the Appendix; 2004 data are limited by covariate availability.) We estimate this model by OLS; statistical tests show no evidence of first-order autocorrelation across 
NOTICE: This is the author's version of a work accepted for publication by Elsevier. Changes resulting from the publishing process, including peer review, editing, corrections, structural formatting and other quality control mechanisms, may not be reflected in this document. Changes may have been made to this work since it was submitted for publication. The definitive version has been published in World Development, Volume 39, Issue 9, 2011. DOI: 10.1016/j.worlddev.2011.02.006

the panels at any conventional significance level $(\mathrm{F}=0.54)$ (Wooldridge 2002). Because we also know the number of survey items used to construct each estimate of perceptions of corruption in each country, we use the inverse of this number (attached to each measurement of the dependent variable) as an analytic weight. Weights are used because each recorded entry summarizes measurements gathered across individuals, across survey instruments, and across question wordings. We do not use the World Bank-provided standard error of each estimate (which reflects uncertainty encapsulated in this measurement process) as a weight because analytic weights based on the number of items used in constructing estimates better reflect uncertainty. ${ }^{11}$ Also note that our data include unbalanced panels, but we account for country-level unmeasured heterogeneity by estimating robust standard errors clustered on the country identifier: one advantage of this approach is that we do not have to make the strict assumptions associated with random effects in panel estimation.

The first model we specify includes polarization and institutional variables. Specifically, we control for the number of veto players in the system and their independence from each another, for the presence of a PR system (OLPR and CLPR), for presidential systems, and for democratization (including nonlinear effects). We also account for income (GDP per capita) because low-income countries have a greater incidence of corruption for numerous reasons (Treisman, 2000). Bureaucrats in developing societies receive salaries that are sufficiently low to entice corrupt behaviour. Low-income societies may lack the institutions for detecting corruption and fraud. Because opportunities in the private sector are harder to come by, grey market activities may expand. Determining the direction of causation is difficult: it is not clear whether countries with low income generate more corruption, or whether corruption makes countries poorer.

We then examine a number of alternative specifications as a series of robustness checks. We first include a measure of federalism; we then include controls for additional institutional factors, including military leadership, ethnolinguistic fractionalization, legal origins, and income inequality. Our Appendix includes a full discussion of our variables, their measurement, and the sources for the data.

\section{Results}

Estimates presented in Table 1 show there is a strong relationship between ideological polarization and corruption. As hypothesized, high levels of political polarization are associated with perceptions that corruption is under control (positive values of the dependent variable). The positive sign on the polarization coefficient confirms Keefer and Stasavage's argument (2003) concerning the importance of veto players' ideology - here, though, in the case of corruption. The results also accord with Alt and Lassen's findings: polarization's correlation with corruption suggests corruption can be constrained by an opposition so long as it is given an institutional role (2005). The estimates confirm Tsebelis's (2002) theoretical insight that party coherence as well as ideological distance (congruence) between actors is crucial for explaining policy outcomes. The number of veto players is not the only important dimension to consider.

\section{[Insert Table 1 about here.]}

We also find the dynamics specified by previous work on corruption are contingent upon the way the model is specified. The second set of results in Table 1 show that the effect of polarization on corruption is located at the endpoint: that high polarization has a strong and significant effect on perceptions - but that the effect of moderate polarization is no different than that for low polarization (the omitted/base case). This result also shows that the effect of polarization when included as an interval-level measure is muted due to its nonlinear contribution to the reduction of perceptions of corruption. The effect is substantial - one half-point on our corruption index.

We want to be very clear about the role of electoral institutions here. While we continue to find effects for electoral institutions, assessing the impact of polarization informs our understanding of public corruption: a more fullyspecified model changes our interpretation of how public electoral institutions influence corruption. Of the traditional concerns regarding electoral design, open-list PR is associated with greater negative perceptions of corruption, which is consistent with Myerson (1993). In Table 1, we also find a negative association between closedlist PR and the control of corruption. Indeed, the effects of open- and closed-list PR system are indistinguishable (F $=0.01$ in a test of the equality of the coefficients); this indicates a general problem with PR systems and corruption, rather than a specific type of Proportional Representation. Presidential regimes are also negatively associated with controlling corruption echoing Gerring and Thacker's results (2004). The role of democracy and its nonlinear 
NOTICE: This is the author's version of a work accepted for publication by Elsevier. Changes resulting from the publishing process, including peer review, editing, corrections, structural formatting and other quality control mechanisms, may not be reflected in this document. Changes may have been made to this work since it was submitted for publication. The definitive version has been published in World Development, Volume 39, Issue 9, 2011. DOI: 10.1016/j.worlddev.2011.02.006

association with perceived corruption is unclear, meaning we do not find support for the findings in Montinola and Jackman (2002). We find no direct effect of increased checks on perceived corruption. As suggested above, Table 1 provides evidence of a positive correlation between economic development and the control of corruption.

Is the statistical relationship between polarization and corruption substantively important? Figure 1 shows the density of the predicted values of the corruption index (higher values indicating lower corruption) across the three values of our polarization measure. The box plots in Figure 1 show higher levels of corruption are associated with lower levels of polarization. The mean predicted index level for countries with the least amount of polarization is 0.20 ; the mean predicted index level for those countries with the highest polarization is 1.07 , suggesting substantial reduction in perceptions of corruption (or alternatively, increases in perceptions that corruption is under control). Moving from the lowest level of polarization to the highest is equivalent to the predicted values of corruption equal to moving from those recorded by Lesotho to those recorded by Chile. Of course, this illustration is not exact since the predicted corruption levels for each country depend on estimates at the means of the independent variables, and both Lesotho and Chile vary on dimensions other than polarization. However, this comparison reveals how, on average, countries with higher polarization experience lower levels of corruption.

\section{[Insert Figure 1 about here.]}

The results summarized in Figure 1 are illustrated in two examples: Peru and Bolivia. The World Bank's first measurement of Peruvian corruption occurred in 1996 under the Fujimori regime, which garnered a polarization score of zero due to majority control of Congress. Peru receives a polarization score of one following the elections (2001) that brought Alejandro Toledo to office. Unlike Fujimori, Toledo and his Peru Possible party were forced to form a coalition with the right-wing Independent Moralizing Front in order to shepherd their economic policy agenda through Congress. However, perceptions of corruption actually increased in 2002 and 2004 despite the fall of a corrupt semi-authoritarian regime and the election of Toledo, a centrist opposition leader. In Peru's case, an ideologically indistinct coalition partner did little to reduce perceptions of corruption.

Contrast the Peruvian experience with that of Bolivia, which features a shift from one to two between the World Bank's 1996 and 1998 measurements of corruption. Prior to the 1997 elections, the reform-minded Sanchez de Lozada administration promoted a regimen of neo-liberal reforms under a coalition of centrist and left-leaning parties. The state's policy agenda during this era included a privatization program during which foreign firms purchased up to fifty percent control of public entities in exchange for investment in the domestic economy. Parties in the governing coalition opposed these reforms along with the allegedly corrupt way in which shares of utilities, airlines, railroads and the state oil firm were distributed to foreign owners. These parties occupied a majority of seats in the lower house, but were not able to prevent the implementation of market reforms. Consequently, measurements of corruption in 1996 reflected the perception of an unfettered fire-sale of state assets under the Sanchez de Lozada administration. Measures of corruption following the 1997 presidential elections tell a different tale: former dictator Hugo Banzer ascended to the presidency, but was forced to build a support base representing a broad ideological spectrum of political parties. Gathering a legislative coalition required participation of parties on the left, right, and centre which accompanied a decrease in perceptions of corruption in Bolivia. This decrease in perceptions of corruption is particularly instructive because the Banzer administration did not alter the previous administration's privatization agenda. However, the likelihood of more stringent monitoring by ideologically distinct and hence credible members of the governing coalition increased in 1998 such that perceptions of corruption improved.

\section{Robustness Checks}

We also assessed the robustness of our finding. First, when assessing the role of federalism our results do not accord with Treisman (2000): federalism is not correlated with the higher perceptions of corruption in our model (lower perceptions of its control) (see Table 2). Polarization is robust to the inclusion of this covariate, even though the sample size drops substantially. Whether the coefficient for checks (veto points) is significantly different from zero depends on the specification of our polarization variable.

Second, in addition to electoral rules, type of regime, and polarization, we estimated the correlation between corruption and additional variables representing plausible alternative explanations. For example, we examined the impact military governments have on corruption. An important point of separation between the head of state and the head of the armed forces is fused when the chief executive is a member of the military. Without proper divisions, the 
NOTICE: This is the author's version of a work accepted for publication by Elsevier. Changes resulting from the publishing process, including peer review, editing, corrections, structural formatting and other quality control mechanisms, may not be reflected in this document. Changes may have been made to this work since it was submitted for publication. The definitive version has been published in World Development, Volume 39, Issue 9, 2011. DOI: 10.1016/j.worlddev.2011.02.006

military as an institution becomes exposed to politics and potential capture by interest groups, which could increase the amount of corruption in the system. In certain contexts such as Chile, however, the military may be the only institution capable of effectively controlling corruption, especially at a level visible to the public (Barros, 2002). Given that the degree of corruption may depend on the military's level of professionalism, we have no concrete expectations regarding the correlation between military governments and corruption.

Scholars have also identified ethnolinguistic fractionalization (ELF) as an important barrier to achieving political and economic stability (Easterly and Levine, 1997, Annet, 2001). Extending this work to corruption, high levels of ELF can produce dissatisfaction as minority groups will be underrepresented. This may increase corruption as politicians attempt to buy support from distinct ethnic groups. Fractionalization, however, could also decrease corruption to the extent that it increases ideological polarization.

We also account for the origin of a state's legal system since it may also influence public perceptions of corruption. The endogenous growth literature in economics implicates these origins as an influential factor in determining institutional performance (Acemoglu et. al., 2000). Similarly, Brown demonstrates a strong relationship between a country's former colonizers and the development of human capital (Brown, 2000). We follow research by Treisman (2000) and La Porta, et al.(1997, 2000) and test the expectation that English colonial origins positively influence control of corruption as they afford more property rights to investors than do states operating under the Civil Law tradition.

Finally, income inequality may increase corrupt practices. ${ }^{12}$ Inequality can generate the popular belief that distributional gains by the elite result from collusion with the government through corrupt practices. The polarization of ethnic, political, or social groups around the distribution of material wealth may frequently constitute the central issue in national politics, producing a heightened awareness or fear of corruption (Lichbach, 1989). The measurement of each of these variables is fully discussed in the Technical Appendix.

Table 3 shows that our finding with regard to a direct effect of polarization on corruption perceptions is robust to the inclusion of other covariates. The only other competing explanation that does find support, though, is that income inequality reduces those perceptions. We note that the findings regarding open-list PR and presidential systems are not robust to this specification, and that the effect of checks depends on the categorization of polarization.

\section{[Insert Tables 2 and 3 about here.]}

\section{Conclusion}

We find the composition of the legislature and its position relative to the chief executive is correlated with how corruption is perceived across countries. When broadening the model to account for a variety of socioeconomic factors and fixed effects, we find that some previously significant institutional variables do not appear to be robust to expanded specification of the model. Studies like Kunicová and Rose-Ackerman's connect the theoretical dots between institutions and corruption; those links ignore, however, what Tsebelis considers an important dimension of the veto player schema - the credibility of the veto player himself/herself as a blocking mechanism. ${ }^{13}$ This is what polarization achieves; rather than having a system with separated, but affiliated political viewpoints, our findings suggest that polarization is a statement about the power of dispute.

While in one issue area it may be detrimental to the desired outcome (economic growth), our results imply political polarization may actually produce beneficial consequences in another: the control of corruption. As discussed in our theoretical section, credible commitment and its beneficial consequences may be contingent on the desired behaviour. In terms of economic reform, political polarization may lead to wild swings in macroeconomic policy. Of course, depending on the distribution of seats in the legislature, polarization could also force genuine compromise. In terms of an opposition's credibility as an agent charged with legislative and executive oversight, political polarization provides a higher degree of credible commitment than would a legislature characterized by homogeneous interests. Our findings provide a cautionary tale for the burgeoning literature on institutions and their ability to constrain politicians. Credible commitment can come in a number of different guises: the same level of credible commitment that in some contexts breeds distrust (e.g., economic reform), may simultaneously generate confidence in others (e.g., fighting corruption). 
NOTICE: This is the author's version of a work accepted for publication by Elsevier. Changes resulting from the publishing process, including peer review, editing, corrections, structural formatting and other quality control mechanisms, may not be reflected in this document. Changes may have been made to this work since it was submitted for publication. The definitive version has been published in World Development, Volume 39, Issue 9, 2011. DOI: 10.1016/j.worlddev.2011.02.006

In one sense, we do not provide reasons to be optimistic about taking institutional steps to address the perceptions of corruption. The effect others have found between proportional representation and corruption holds here. Yet, our findings imply that designing policy prescriptions to combat corruption may actually be imprudent in cases absent an ideological check on powerful interests in government. This relationship holds even after we account for the kinds of attributes that are extremely difficult for countries to change: income inequality, wealth, and other fixed effects that are associated with each country.

In another sense, there is an important reason to be optimistic. Perceptions of corruption do depend on political institutions that are difficult to change; although some institutions change over time, constitutional features such as legislative-executive relations, electoral rules, and even ballot structures are often difficult to replace. More important, with respect to corruption, is an ideologically distinct opposition. Although viable oppositions are not necessarily easy to come by, they can be produced by a variety of means. Given the importance of ideological polarization demonstrated above, one fruitful direction for future research involves explaining the existence of political polarization itself.

\footnotetext{
${ }^{1}$ For an excellent review of the literature see Treisman (2000). Persson and Tabellini (2003) offer an updated list of work emphasizing institutions and corruption. Montinola and Jackman (2002) include an exhaustive discussion of work on democracy and corruption.

${ }^{2}$ Our results indicate presidential regimes are perceived as more corrupt than parliamentary systems. See Table I.

${ }^{3}$ Frye's argument runs counter to Tsebelis' claim in that greater ideological polarization causes private actors to have less faith that policy stability will be maintained.

${ }^{4}$ For example, see Spiller and Tomasi (2003) on Argentine politics.

${ }^{5}$ Gerring and Thacker (2004) provide an excellent theoretical discussion and empirical test of presidential vs. parliamentary impact on corruption.

${ }^{6}$ Treisman (2000) and Gerring and Thacker (2004) thoroughly explore the relationship between federalism and corruption.
}

${ }^{7}$ The orientation is given by Beck, et al.'s source material on the party's name, platform, voting record, etc. The values assigned to this variable were checked against the Huber-Inglehart (1995) database on ideological orientation of parties.

${ }^{8}$ This method of classification may strike one as counterintuitive since ideological opposition is clearly present in many systems coded "0". However, only a few observations in our data match this coding and our results do not change appreciably when they are excluded from our estimates. Results available upon request.

${ }^{9}$ The Governance Matters V data are available at: http://web.worldbank.org/WBSITE/EXTERNAL/WBI/EXTWBIGOVANTCOR/0,contentMDK:20771165 menuPK:1866365 pagePK:6416844 5 piPK:64168309 theSitePK:1740530,00.html

\footnotetext{
${ }^{10}$ We performed cross-sectional regressions for each year of the sample and found that the results held for five out of the six years: a strong confirmation of our results' stability with respect to the panel structure of the data.

${ }^{11}$ Papers that do account for uncertainty by using the standard error of the estimated score for each country engage in importance weighting (Kunicová and Rose-Ackerman 2005), which is substantively different.

${ }^{12}$ For example, recent work on China notes a connection between social unrest and growing economic inequality.

${ }^{13}$ An alternative explanation for the reduced significance of institutions is contingent upon their multicollinearity with new control variables. For instance, British legal origins and single member districts are correlated with having been a British colony. Using Variance Inflation Factors we find no evidence of significant collinearity between these covariates. It is more likely that the changing significance of the polarization coefficient is due to the smaller sample size.
} 
NOTICE: This is the author's version of a work accepted for publication by Elsevier. Changes resulting from the publishing process, including peer review, editing, corrections, structural formatting and other quality control mechanisms, may not be reflected in this document. Changes may have been made to this work since it was submitted for publication. The definitive version has been published in World Development, Volume 39, Issue 9, 2011. DOI: 10.1016/j.worlddev.2011.02.006

\section{TABLES AND FIGURES}

TABLE 1. Models of Corruption Perceptions

\begin{tabular}{|c|c|c|c|c|c|c|}
\hline Variable & Coefficient & SE & & Coefficient & SE & \\
\hline Ideological Polarization & 0.226 & 0.059 & $* * *$ & & & \\
\hline Moderate Polarization & & & & 0.060 & 0.172 & \\
\hline High Polarization & & & & 0.425 & 0.118 & $* * *$ \\
\hline Open List PR & -0.444 & 0.177 & ** & -0.405 & 0.179 & $*$ \\
\hline Closed List PR & -0.433 & 0.133 & $* *$ & -0.413 & 0.134 & $* *$ \\
\hline Presidential & -0.441 & 0.107 & $* * *$ & -0.419 & 0.109 & $* * *$ \\
\hline Checks & -0.053 & 0.051 & & -0.033 & 0.057 & \\
\hline Polity & 0.054 & 0.077 & & 0.057 & 0.077 & \\
\hline Polity - quadratic term & -0.001 & 0.003 & & -0.001 & 0.003 & \\
\hline Ln GDP Per Capita & 0.768 & 0.092 & $* * *$ & 0.773 & 0.091 & $* * *$ \\
\hline Constant & -6.684 & 0.921 & $* * *$ & -6.781 & 0.920 & $* * *$ \\
\hline $\mathrm{N}$ & 541 & & & 541 & & \\
\hline Maximum number of countries & 102 & & & 102 & & \\
\hline $\mathrm{F}$ & 45.26 & $* * *$ & & 42.85 & $* * *$ & \\
\hline Root MSE & 0.566 & & & 0.565 & & \\
\hline & 0.747 & & & 0.749 & & \\
\hline
\end{tabular}

Robust Standard Errors were used above.

* indicates significance at better than 0.05 (two-tailed test).

** indicates significance at better than 0.01 (two-tailed test).

$* * *$ indicates significance at better than 0.001 (two-tailed test). 
NOTICE: This is the author's version of a work accepted for publication by Elsevier. Changes resulting from the publishing process, including peer review, editing, corrections, structural formatting and other quality control mechanisms, may not be reflected in this document. Changes may have been made to this work since it was submitted for publication. The definitive version has been published in World Development, Volume 39, Issue 9, 2011. DOI: 10.1016/j.worlddev.2011.02.006

TABLE 2. Robustness Check I: Models, Federalism Included

\begin{tabular}{|c|c|c|c|c|c|c|}
\hline Variable & Coefficient & SE & & Coefficient & SE & \\
\hline Ideological Polarization & 0.254 & 0.057 & $* * *$ & & & \\
\hline Moderate Polarization & & & & 0.114 & 0.180 & \\
\hline High Polarization & & & & 0.486 & 0.113 & $* * *$ \\
\hline Open List PR & 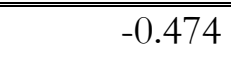 & 0.198 & ** & -0.444 & 0.202 & ** \\
\hline Closed List PR & -0.560 & 0.127 & $* * *$ & -0.542 & 0.129 & $* * *$ \\
\hline Presidential & -0.433 & 0.120 & $* *$ & -0.410 & 0.124 & $* *$ \\
\hline Checks & -0.107 & 0.052 & $*$ & -0.090 & 0.060 & \\
\hline Polity & 0.021 & 0.093 & & 0.022 & 0.093 & \\
\hline Polity - quadratic term & 0.001 & 0.004 & & 0.001 & 0.004 & \\
\hline Ln GDP Per Capita & 0.814 & 0.102 & $* * *$ & 0.816 & 0.102 & $* * *$ \\
\hline Federalism & -0.006 & 0.080 & & -0.003 & 0.079 & \\
\hline Constant & -6.747 & 1.056 & $* * *$ & -6.817 & 1.054 & $* * *$ \\
\hline $\mathrm{N}$ & 407 & & & 407 & & \\
\hline Maximum number of countries & 75 & & & 75 & & \\
\hline $\mathrm{F}$ & 49.54 & $* * *$ & & 49.02 & $* * *$ & \\
\hline Root MSE & 0.508 & & & 0.507 & & \\
\hline $\mathrm{R}^{2}$ & 0.804 & & & 0.805 & & \\
\hline
\end{tabular}

Robust Standard Errors were used above.

$*$ indicates significance at better than 0.05 (two-tailed test).

** indicates significance at better than 0.01 (two-tailed test).

*** indicates significance at better than 0.001 (two-tailed test). 
NOTICE: This is the author's version of a work accepted for publication by Elsevier. Changes resulting from the publishing process, including peer review, editing, corrections, structural formatting and other quality control mechanisms, may not be reflected in this document. Changes may have been made to this work since it was submitted for publication. The definitive version has been published in World Development, Volume 39, Issue 9, 2011. DOI: 10.1016/j.worlddev.2011.02.006

TABLE 3. Robustness Check II: Models, Additional Covariates Included

\begin{tabular}{|c|c|c|c|c|c|c|}
\hline Variable & Coefficient & SE & & Coefficient & SE & \\
\hline Ideological Polarization & 0.217 & 0.051 & $* * *$ & & & \\
\hline $\begin{array}{l}\text { Moderate Polarization } \\
\text { High Polarization }\end{array}$ & & & & $\begin{array}{r}-0.055 \\
0.395\end{array}$ & $\begin{array}{l}0.162 \\
0.100\end{array}$ & $* * *$ \\
\hline Open List PR & $2-0.245$ & 0.188 & & -0.187 & 0.184 & \\
\hline Closed List PR & -0.413 & 0.150 & $* *$ & -0.387 & 0.147 & $* *$ \\
\hline Presidential & -0.186 & 0.157 & & -0.136 & 0.148 & \\
\hline Checks & -0.103 & 0.048 & * & -0.069 & 0.055 & \\
\hline Polity & -0.033 & 0.099 & & -0.028 & 0.098 & \\
\hline Polity - quadratic term & 0.002 & 0.004 & & 0.001 & 0.004 & \\
\hline Ln GDP Per Capita & 0.891 & 0.105 & $* * *$ & 0.888 & 0.104 & $* * *$ \\
\hline Federalism & -0.079 & 0.083 & & -0.069 & 0.082 & \\
\hline Military & -0.363 & 0.289 & & -0.396 & 0.287 & \\
\hline Income Inequality & -0.017 & 0.006 & $* *$ & -0.017 & 0.006 & $* *$ \\
\hline Ethnolinguistic Fractionalization & 0.277 & 0.243 & & 0.210 & 0.241 & \\
\hline English Origins & 0.202 & 0.155 & & 0.209 & 0.149 & \\
\hline Constant & -6.351 & 1.176 & $* * *$ & -6.389 & 1.165 & $* * *$ \\
\hline $\mathrm{N}$ & 352 & & & 352 & & \\
\hline Maximum number of countries & 64 & & & 64 & & \\
\hline $\mathrm{F}$ & 42.38 & $* * *$ & & 42.38 & $* * *$ & \\
\hline Root MSE & 0.466 & & & 0.466 & & \\
\hline $\mathrm{R}^{2}$ & 0.84 & & & 0.84 & & \\
\hline
\end{tabular}

Robust Standard Errors are used above.

* indicates significance at better than 0.05 (two-tailed test).

** indicates significance at better than 0.01 (two-tailed test).

*** indicates significance at better than 0.001 (two-tailed test).

Figure 1: Polarization and Corruption Perceptions

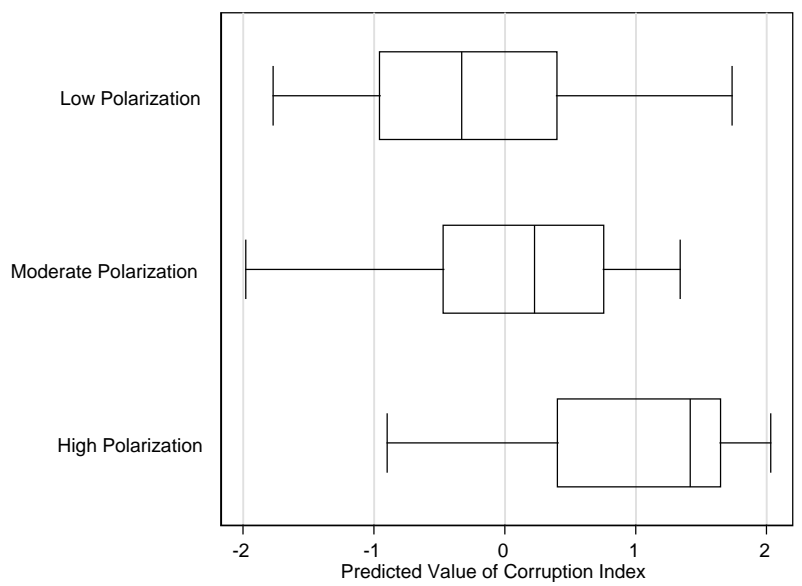


NOTICE: This is the author's version of a work accepted for publication by Elsevier. Changes resulting from the publishing process, including peer review, editing, corrections, structural formatting and other quality control mechanisms, may not be reflected in this document. Changes may have been made to this work since it was submitted for publication. The definitive version has been published in World Development, Volume 39, Issue 9, 2011. DOI: 10.1016/j.worlddev.2011.02.006

TABLE A1. Descriptive Statistics

\begin{tabular}{l|r|r}
\hline \hline Variable & Mean & Std. Dev. \\
\hline \hline Public Corruption & 0.190 & 1.116 \\
Ideological Polarization & 0.617 & 0.863 \\
Open List PR & 0.155 & 0.362 \\
Closed List PR & 0.475 & 0.500 \\
Presidential & 0.521 & 0.500 \\
Checks & 3.120 & 1.404 \\
Polity & 15.163 & 5.983 \\
Polity - quadratic term & 265.636 & 145.943 \\
Ln GDP Per Capita & 8.846 & 1.020 \\
Federalism & 0.973 & 0.852 \\
Military & 0.118 & 0.323 \\
Income Inequality & 41.947 & 11.755 \\
Ethnolinguistic Fractionalization & 0.426 & 0.274 \\
English Origins & 0.288 & 0.453 \\
\hline \hline
\end{tabular}

(See the Appendix for a description of the variables and their sources.)

TABLE A3. Robustness Check III: Models, Additional Covariates Included, Averaged Data

\begin{tabular}{|c|c|c|c|}
\hline Variable & Coefficient & SE & \\
\hline Ideological Polarization & 0.330 & 0.089 & $* * *$ \\
\hline \multicolumn{4}{|l|}{$\begin{array}{l}\text { Moderate Polarization } \\
\text { High Polarization }\end{array}$} \\
\hline "Open List PR & -0.287 & 0.207 & \\
\hline Closed List PR & -0.511 & 0.180 & $* *$ \\
\hline Presidential & -0.087 & 0.165 & \\
\hline Checks & -0.155 & 0.069 & $*$ \\
\hline Polity & 0.005 & 0.124 & \\
\hline Polity - quadratic term & 0.001 & 0.005 & \\
\hline Ln GDP Per Capita & 0.838 & 0.146 & $* * *$ \\
\hline Federalism & -0.016 & 0.096 & \\
\hline Military & -0.282 & 0.364 & \\
\hline Income Inequality & -0.018 & 0.007 & $*$ \\
\hline Ethnolinguistic Fractionalization & 0.095 & 0.275 & \\
\hline English Origins & 0.169 & 0.175 & \\
\hline Constant & -6.050 & 1.693 & $* * *$ \\
\hline $\mathrm{N}$ & 73 & & \\
\hline Maximum number of countries & 73 & & \\
\hline $\mathrm{F}$ & 28.09 & $* * *$ & \\
\hline Root MSE & 0.497 & & \\
\hline $\mathrm{R}^{2}$ & 0.84 & & \\
\hline
\end{tabular}


NOTICE: This is the author's version of a work accepted for publication by Elsevier. Changes resulting from the publishing process, including peer review, editing, corrections, structural formatting and other quality control mechanisms, may not be reflected in this document. Changes may have been made to this work since it was submitted for publication. The definitive version has been published in World Development, Volume 39, Issue 9, 2011. DOI: 10.1016/j.worlddev.2011.02.006

\section{Technical Appendix}

This appendix describes variables collected for the countries included in this study. Much of our data was generated by projects at the World Bank: The Database on Political Institutions (DPI) and the Governance Matters database. The former offers cross-country data chronicling the political institutions of 177 states whereas the latter measures perceptions of governance in 213. The data stem from work performed by Beck, et al. (2001) and Kaufmann, et al. (2003). The variables we employ are catalogued below. ${ }^{14}$ Table A1 presents all descriptive statistics for these variables.

\section{[Insert Table A1 about here.]}

Proportional Representation. This variable describes whether a state uses proportional representation to elect all or a portion of its legislators. A political system is coded "1" if either chamber of the legislature is elected based on the percent of votes received by their party and/or if Beck, et al.'s sources specifically refer to the system in question as "proportional." The state is coded " 0 " if these conditions do not apply. N/A is recorded if the Legislative Index of Electoral Competitiveness for the country is 4 or lower, meaning that there is competition for seats, albeit in a oneparty system. We further divide PR systems into open and closed list. CLPR (Closed List) refers to systems where voters cannot express preferences within a list - that is, if the position on a party's candidate list combined with the number of votes received by the party is the sole determinant of whether a candidate is elected or not. OLPR (Open List) systems allow voters to select their favoured party as well as favoured candidate within the party. Source: Beck, et al., 2001

Presidential Systems. This variable designates political systems as either presidential, assembly-elected presidential or parliamentary. The system is coded presidential (0) if a single executive is elected by popular vote. Additionally, a system is coded presidential if the chief executive is elected by an assembly and can only be recalled by a twothirds vote or dissolution of the assembly. The system is coded " 1 " if the assembly elects, but cannot recall the chief executive. Finally, in cases where both a president and prime minister exist, a system is deemed presidential only after passing a three-part test. First, the president must be able to veto legislation while the parliament may only override if it possesses a supermajority. Second, the president must be allowed to appoint and dismiss cabinet ministers (including the PM) and to dissolve parliament. Third, Beck, et al. classify a system as presidential (0) if the available data does not clarify the executive's abilities on the first two counts, yet Beck, et al.'s sources still refer to the president as the key decision-maker. The system is coded as parliamentary (2) if the preceding conditions do not hold. We distinguish between systems with fully independent presidents (1) and others, including parliamentary systems and those where the assembly names the president. Source: Beck, et al., 2001.

Checks. This measure refers to the number of institutional veto players in the political system and adjusts for whether these veto players are independent of one another as determined by the level of electoral competitiveness in a system, their respective party affiliations, and the electoral rules employed. Additionally, Beck, et al. employ Roubini and Sachs' Legislative Index of Electoral Competitiveness to generate scores for this variable. If the index is less than four, the "checks" measure is set equal to one since, irrespective of the formal constitutional statutes, checks on officials are unlikely to be binding if legislative elections are uncompetitive. For states exhibiting values of the electoral competitiveness index greater than or equal to four, the checks variable is increased beyond one by the number of veto players in the system. For the use of this variable, see Keefer and Stasavage (2003). Source: Beck, et al., 2001.

Polity. The Polity variable consists of a score assigned to each country based on the level of democracy vs. autocracy within its political system. These distinctions are based on the general "openness" or "closedness" of political institutions as determined by Polity IV scholars through examination of numerous indicators such as the constraints on the chief executive, the regulation and competitiveness of participation, the openness of executive recruitment, etc. Scores are generated by subtracting aggregate "autocracy" from "democracy" to create a range of 10 to 10 with ten being the most democratic and -10 the most autocratic for 2000; we rescale this to range from 0 to 20. Following Montinola and Jackman (2002), we include in the regression both polity and its square. Inclusion or exclusion of the squared term does not affect the estimates reported in Table 1. Source: Polity IV data set developed by Gurr, et al (2005). 
NOTICE: This is the author's version of a work accepted for publication by Elsevier. Changes resulting from the publishing process, including peer review, editing, corrections, structural formatting and other quality control mechanisms, may not be reflected in this document. Changes may have been made to this work since it was submitted for publication. The definitive version has been published in World Development, Volume 39, Issue 9, 2011. DOI: 10.1016/j.worlddev.2011.02.006

Ln GDP per Capita. This variable records the natural log of each state's per capita Gross Domestic Product for each year in the database. GDP per capita is in 2000 dollars and is adjusted for purchasing power parity. Source: World Bank, 2006.

Federalism. This variable describes whether the state or provincial governments are locally elected. The measure records a zero if neither the local executive nor the local legislature is directly elected by the population they govern. The data point is coded as a one, however, if either is directly elected and the other is indirectly elected. Finally, a score of two for this variable signifies that both local executive and legislature are directly elected. Finally, in cases where multiple tiers of sub-national government exist, Beck, et al. consider the highest level to be the state/provincial level. Source: Beck et. al., 2001.

Military. This variable indicates whether the state's chief executive is a military officer. A “ 1 ” is recorded if Beck, et al.'s sources (Europa, World Handbook) include a rank in their title, "0" if they do not. Chief executives are listed as officers for the duration of their term if they had not formally retired prior to the assumption of office. If chief executives were formally retired military officers upon taking office, then this variable is scored as " 0 ". Source: Beck et. al., 2001.

Ethnolinguistic Fractionalization. Our ELF data are an average of three indices created by Philip Roeder (2001). One index calculates scores with subgroup data where available (e.g., Ute, Blackfoot, Crow vs. the catch-all "Indigenous"), another excludes racial distinctions among groups that do not dramatically alter linguistic/cultural patterns (e.g., black and white Americans). A third classifies racially distinct sub-groups as independent of one another regardless of their linguistic similarity. The scores generated are a fraction and represent the chance that two random draws will produce individuals from different ethnolinguistic groups. Source: ELF Indices, 1961 and 1985 (Roeder, 2001).

English Origins. An English origin dummy variable is generated to reflect legal attributes such as judicial vs. legislative precedent, rights to private property, and the general rights of the individual relative to the state. As the literature identifies the impact these aspects of a legal system have on institutional performance we feel it appropriate to include them in our model regarding the control of corruption. In general English legal systems are coded as " 1 " for former colonies and all others are coded as zero in keeping with La Porta et. al.'s data on the subject. Source: La Porta, et al., 1997.

Income Inequality. The Gini index measures the level of income inequality within society and is recorded as a number between " 0 " and " 1 ", where " 0 " describes perfect equality (everyone has identical income) and " 1 " refers to perfect inequality (one person earns all income while all others earn nothing). If the area between the line of perfect equality and the Lorenz curve is $A$, and the area underneath the Lorenz curve is $B$, the Gini coefficient is $A /(A+B)$. This is expressed in our data as the numerical equivalent of this percentage, which is always between 0 and 100. Source: World Income Inequality Database V 2.0a, 2005. 
NOTICE: This is the author's version of a work accepted for publication by Elsevier. Changes resulting from the publishing process, including peer review, editing, corrections, structural formatting and other quality control mechanisms, may not be reflected in this document. Changes may have been made to this work since it was submitted for publication. The definitive version has been published in World Development, Volume 39, Issue 9, 2011. DOI: 10.1016/j.worlddev.2011.02.006

\section{Bibliography}

Acemoglu, D., Johnson, S., \& Robinson, J. (2000) The Colonial Origins of Comparative Development: An Empirical Investigation. American Economic Review, 91(5), 1369-1401.

Alt, J. E., \& Lassen D. D. (2005) Political and Judicial Checks on Corruption: Evidence from American State Governments. EPRU Working Paper Series, University of Copenhagen.

— (2003) The Political Economy of Institutions and Corruption in American States. Journal of Theoretical Politics, 15(3), 341-365.

Annet, A. (2001) Social Fractionalization, Political Instability, and Size of Government. Washington, D.C.: International Monetary Fund.

Baldez, L., \& Carey J. (1999) Presidential Agenda Control and Spending Policy: Lessons from General Pinochet's Constitution. American Journal of Political Science, 43(1), 29-55.

Bardhan, P. (1997) Corruption and Development: A Review of Issues. Journal of Economic Literature, 35(3), 13201346.

Barros, R. (2002)Constitutionalism and Dictatorship: Pinochet, the Junta, and the 1980 Constitution. New York: Cambridge University Press.

Beck, T., Clarke, G., Groff, A., Keefer, P., \& Walsh, P. (2001) New Tools in Comparative Political Economy: The Database of Political Institutions. World Bank Economic Review, 15(1), 165-176.

Bingham-Powell Jr., G. (2000) Elections as Instruments of Democracy. New Haven, CT: Yale University Press.

Brown, D. S. (2000) Democracy, Colonization, and Human Capital in Sub-Saharan Africa. Studies in Comparative International Development, 35(1), 20-41.

Carey, J. M., \& Shugart, M. S. (1995) Incentives to Cultivate a Personal Vote: A Rank-Ordering of Electoral Formulas. Electoral Studies, 14(4), 417-439.

Cox, G., \& Morganstern, S. (2001) Latin America's Reactive Assemblies and Proactive Presidents. Comparative Politics, 33(2), 171-189.

Easterly, W., \& Levine, R. (1997) Africa's Growth Tragedy: Policies and Ethnic Divisions. Quarterly Journal of Economics, 112(4), 1203-1250.

Ehrlich, I., \& Lui, F. T. (1999) Bureaucratic Corruption and Endogenous Economic Growth. Journal of Political Economy, 107(6), Part 2: Symposium on the Economic Analysis of Social Behaviour in Honor of Gary S. Becker, S270-S293.

Frye, T. (2002) The Perils of Polarization: Economic Performance in the Postcommunist World. World Politics, 54(3), 308-337.

Gerring, J. \& Thacker, S. C. (2004) Political Institutions And Corruption: The Role Of Unitarism And Parliamentarism. British Journal Of Political Science, 34, 295-330.

Gurr, T. R., Marshall, M., \& Jaggers, K. (2005) Polity IV Project: Political Regime Characteristics and Transitions, 1800-2003. Web site: http://www.cidcm.umd.edu/inscr/polity/

Huber, J. and Inglehart, R., “Expert Interpretations of Party Space and Party Locations in 42 Societies,” Party Politics Vol. 1, no. No. 1 (January 1, 1995): 73-111. 
NOTICE: This is the author's version of a work accepted for publication by Elsevier. Changes resulting from the publishing process, including peer review, editing, corrections, structural formatting and other quality control mechanisms, may not be reflected in this document. Changes may have been made to this work since it was submitted for publication. The definitive version has been published in World Development, Volume 39, Issue 9, 2011. DOI: 10.1016/j.worlddev.2011.02.006

Kaufman, D., Kraay, A. \& Mastruzze, M. (2003) Governance Matters III: Governance Indicators for 19996-2002. In World Bank Policy Research Working Paper. Washington, D.C.

Kaufman, D., \& Wie, S. J. (1999) Does 'Grease Money' Speed up the Wheels of Commerce? In Bureau of Economic Research Working Paper. Washington, D.C.: National Bureau of Economic Research.

Keefer, P., \& Stasavage, D. (2003) The Limits of Delegation: Veto Players, Central Bank Independence, and the Credibility of Monetary Policy. American Political Science Review, 97(3), 407-423.

Khan, A., \& Riskin, C. (1998) Income Inequality in China: Composition, Distribution, and Growth of Household Income, 1988-1995. The China Quarterly, 154, 221-225.

Kunicova, J., \& Rose-Ackerman, S. (2005) Electoral Rules and Constitutional Structures as Constraints on Corruption. British Journal of Political Science, 35(4), 573-606.

La Porta, R., Lopez de Silanes, F., Shleifer, A., \& Vishny, R. W. (2000) Investor Protection and Corporate Governance. Journal of Financial Economics, 58(1), 3-28. . Legal Determinants of External Finance. Journal of Finance, 52(3), 1131-1150.

Lichbach, M. (1989) An Evaluation of "Does Economic Inequality Lead to Political Conflict" Studies. World Politics, 41(4), 431-470.

Lijphart, A. (1984) Measures of Cabinet Durability: A Conceptual and Empirical Evaluation. Comparative Political Studies, 17(2), 265-279.

. (1999) Patterns of Democracy : Government Forms and Performance in Thirty-Six Countries. New Haven, CT: Yale University Press.

Mainwaring, S. (1995) Presidentialism, Multipartyism, and Democracy. Comparative Political Studies, 26(2), 198228.

Mauro, P. (1995) Corruption and Growth. The Quarterly Journal of Economics, 110(3), 681-712.

Montinola, G., \& Jackman, R. (2002) Sources of Corruption: A Cross-Country Study. British Journal of Political Science, 32(1), 147-170.

Murphy, K. M., Shliefer, A., \& Vishny, R. W. (1993) Why Is Rent-Seeking So Costly to Growth? American Economic Review, 83(2), 409-414.

Myerson, R. B. (1991) Effectiveness of Electoral Systems for Reducing Government Corruption: A Game-Theoretic Analysis. In Discussion Paper. Evanston.

. (1993) Incentives to Cultivate Favored Minorities under Alternative Electoral Systems. American Political Science Review, 87(4), 856-869.

Panizza, U. (2001) Electoral Rules, Political Systems and Institutional Quality. Economic and Politics, 13(3), 311342.

Persson, T., Roland, G., \& Tabellini, G. (1996) Separation of Powers and Accountability: Towards a Formal Approach to Comparative Politics. CEPR Discussion Paper 1475.

Persson, T., \& Tabellini, G. (2003) The Economic Effects of Constitutions. Cambridge, MA: MIT Press.

Roeder, P. G. (2001) Ethnolinguistic Fractionalization (ELF) Indices, 1961 and 1985. Web site: http//:weber.ucsd.edul proederlelf.htm 
NOTICE: This is the author's version of a work accepted for publication by Elsevier. Changes resulting from the publishing process, including peer review, editing, corrections, structural formatting and other quality control mechanisms, may not be reflected in this document. Changes may have been made to this work since it was submitted for publication. The definitive version has been published in World Development, Volume 39, Issue 9, 2011. DOI: 10.1016/j.worlddev.2011.02.006

Rozelle, S. (1996) Stagnation without Equity: Patterns of Growth and Inequality in China's Rural Economy. The China Journal, 35, 63-92.

Seddon, J., Gaviria, A., Panizza, U., \& Stein, E. (2003) Political Particularism around the World. World Bank Economic Review, 17, 133-143.

Shugart, M. S. (1999) Presidentialism, Parliamentarism, and the Provision of Collective Goods in Less-Developed Countries. Constitutional Political Economy, 10(1), 53-88.

Spiller, P., \& Tomasi, M. (2003) The Institutional Foundations of Public Policy: A Transactions Approach with Application in Argentina. Journal of Law, Economics, and Organization 19, 281-306.

The Economist. (2005, June 4th) A Regime Changes. The Economist.

Treisman, D. (2000) The Causes of Corruption: A Cross-National Study. Journal of Public Economics, 76(3), 399457.

Tsebelis, G. (1995) Decision Making in Political Systems: Veto Players in Presidentialism, Parliamentarism, Multicameralism and Multipartyism. British Journal of Political Science, 25(3), 289-325.

—. (2002) Veto Players. Princeton, NJ: Princeton University Press.

United Nations University World Institute for Development Economics Research. (2005) World Income Inequality Database V 2.0a.

Wooldridge, J. M. (2002) Econometric Analysis of Cross Section and Panel Data. Cambridge, MA: MIT Press.

World Bank. (2006) World Tables. Washington, DC. 